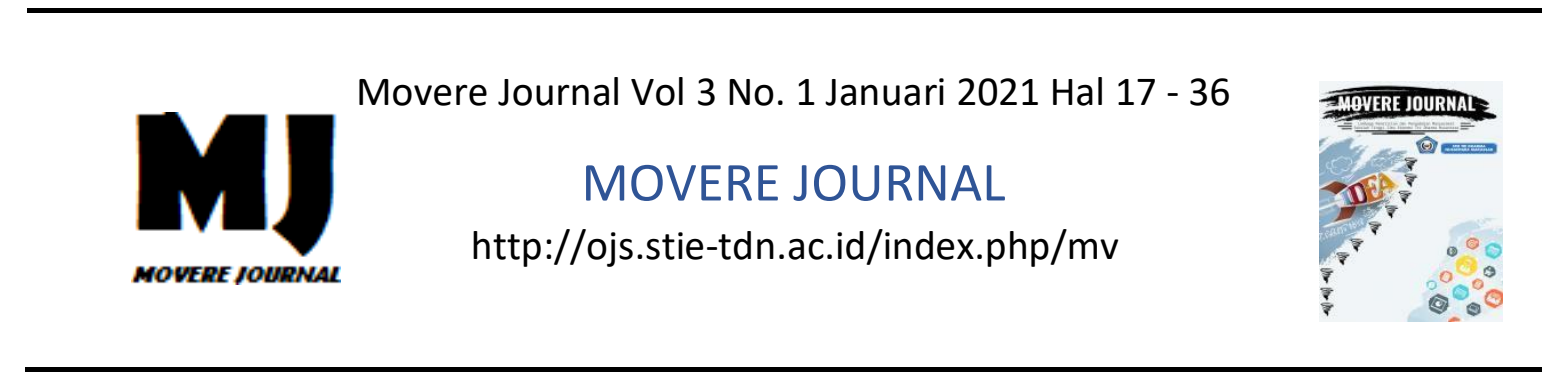

\title{
ANALISIS SUMBER DAN PENGGUNAAN KAS PADA PT. MULIA INDUSTRINDO, Tbk.
}

\author{
JUMRIA $^{1}$, RAHMADANI ${ }^{2}$. \\ Sekolah Tinggi Ilmu Ekonomi Tri Dharma Nusantara Makassar ${ }^{1,2}$. \\ Email: jumriaria@gmail.com ${ }^{1}$, rahmadany62@gmail.com².
}

\begin{abstract}
Abstrak : Penelitian ini bertujuan untuk mengetahui sumber dan penggunaan kas pada PT. Mulia Industrindo, Tbk. Periode 2018-2019 Penelitian ini menggunakan data kualitatif dan kuantitatif serta sumber data yang digunakan adalah data sekunder. Metode analisis yang digunakan yaitu analisis deskriptif. Berdasarkan hasil penelitian analisis sumber dan penggunaan kas dimana terjadi peningkatan kas sebesar Rp 81.286.299.000 sumber kas pada tahun 2019 sebesar Rp 788.957.896.000 sedangkan penggunaan kas pada tahun 2019 sebesar Rp 707.671.597.000 sumber kas terbesar di tahun 2019 berasal dari Liabilitas jangka panjang utang bank sebesar Rp175.459.256.000 sedangkan penggunaan kas terbesar di tahun 2019 berasal dari Aset keuangan lainnya sebesar Rp 140.611.874.000 sehingga dapat disimpulkan bahwa sumber kas lebih besar dari penggunaan kas.
\end{abstract}

\section{Kata kunci: sumber, penggunaan kas}

Abstract : This study aims to determine the source and the use of cash at PT. Mulia Industrindo, Tbk. period 2018-2019. This research uses both qualitative and quantitative data and the data source used is secondary data. The analysis method used is descriptive analysis. Based on the result of the research, the analysis of the sources and the use of cash there was an increase in cash of Rp81,286,299,000. The source of cash in 2019 Rp788,957,896,000, while the use of cash in 2019 was Rp707,671,597,000. The largest source of cash in 2019 came from long-term debt liabilities in bank Rp175,459,256,000, whereas the largest cash use in 2019 came from other financial assets Rp140,611,874,000. Furthermore, it can be concluded that the source of cash is greater than the use of cash.

Keywords : the source and the use of cash 


\section{PENDAHULUAN}

\section{A. Latar Belakang}

Perusahaan merupakan suatu organisasi bisnis yang didirikan oleh sekelompok orang yang memiliki tujuan yang sama. Secara umum perusahaan memiliki tujuan utama untuk memperoleh laba bagi pertumbuhan perusahaan. agar tujuan tersebut dapat tercapai maka manajemen harus mempunyai tanggung jawab utama untuk membuat perencanaan, melakukan pengendalian yang menjaga sumber daya yang terdapat dalam perusahaan secara optimal dan mengarahkannya pada pencapaian tujuan yang telah ditetapkan dengan cara yang efektif dan efesien.Untuk menjalankan tanggung jawab tersebut maka di perlukan manajer-manajer yang dapat mengelolah bagian-bagian perusahaan, misalnya bagian personalia, produksi, pemasaran dan bagian keuangan, dimana pada pelaksanaannya akan menghadapi berbagai masalah baik dari dalam maupun dari luar perusahaa.

Salah satunya masalah keuangan yaitu bagaimana mencari sumber kas dan penggunaan kas baik dalam artian kas maupun modal kerja. Kas dikelola dengan baik sangat diperlukan dalam administrasi, karena kas merupakan proyeksi mengenai penerimaan dan pengeluaran kas dalam periode tertentu. Dalam hal ini kas memiliki tujuan pokok untuk merencanakan penganggaran kas yang seoptimal mungkin, yaitu rencana untuk menyediakan kas yang cukup baik dalam jumlah maupun waktunya.

Jumlah uang kas yang berlebihan ataupun yang kurang, keduanya mempunyai akibat negative bagi perusahaan, kekurangan kas dapat mengakibatkan tidak terbayarnya berbagai kewajiban seperti hutang gaji, hutang dagang pada rekaman bahan baku dan sebagainya. Hal ini akan menurunkan produktivitas kerja serta merugikan nama baik bagi perusahaan.

Oleh karena itu pimpinan perusahaan harus dapat melaksanakan pengelolaan dana dan pengaturan dana (dalam artian kas) dengan sebaikbaiknya sehingga dalam jangka pendek yang tersedia dapat memenuhi kebutuhan baik dalam jumlah maupun waktunya, oleh karena itu perlu diperhatikan tiga hal pokok yaitu: pertama administrasi kas harian yaitu penyajian laporan kas yang menggambarkan struktur penerimaan dan pengeluaran kas serta saldo kas dapat diketahui dengan cepat oleh manajer untuk dijadikan bahan informasi dalam pengambilan keputusan. Kedua adalah anggaran kas yang menggambarkan taksiran atau perkiraan penerimaan atau pengeluaran kas selama selama periode tertentu di masa yang akan datang. Ketiga adalah menentukan jumlah kas optimum yaitu menetapkan jumlah kas sedemikian rupa sehingga kelancaran operasi perusahaan terjamin. Penerimaan dan pengeluaran kas dalam perusahaan dan berlangsung selama hidupnya perusahaan. Dengan demikian aliran kas itu bagaikan darah yang terus menerus mengalir dalam tubuh perusahaan yang memungkinkan perusahaan itu dapat melangsungkan hidupnya.

\section{B. Rumusan Masalah}

Uraian latar belakang diatas, maka rumusan masalah dalam penelitian ini adalah apakah sumber lebih besar dari penggunaan kas pada PT. Mulia Industrindo, Tbk., periode 2018-2019 ? 


\section{Tujuan Penelitian}

Berdasarkan rumusan masalah yang telah dikemukakan, maka tujuan dalam penelitian ini adalah untuk mengetahui sumber dan penggunaan kas pada PT. Mulia Industrindo, Tbk.

\section{Hipotesis}

Berdasarkan latar belakang dan rumusan masalah diatas, maka hipotesis dari penelitian ini adalah diduga bahwa sumber lebih besar dari penggunaan kas pada PT. Mulia Industrindo, Tbk., periode 20182019.

\section{A. Pengertian Kas}

\section{TINJAUAN PUSTAKA}

Kas berperang penting dalam menunjang aktivitas operasional dan non operasional perusahaan. Oleh karena itu, kas harus direncanakan dengan baik agar kas dapat digunakan dengan tepat. Kas dalam suatu perusahaan tidak boleh kecil maupun besar dari pada pengeluaran yang dibutuhkan. Apabila jumlah kas terlalu dari pengeluaran yang dibutuhkan kecil maka perusahaan tidak dapat memenuhi kebutuhan operasionalnya. Dan apabila jumlah kas terlalu besar daripada pengeluaran yang dibutuhkan maka kemungkinan uang yang ada diperusahaan dapat menganggur (idle cash). Uang menganggur (idle cash) merupakan sejumlah dana yang belum dimanfaatkan sehingga tidak dapat memberikan pendapatan bagi perusahaan.

Menurut Jumingan (2017:97), kas merupakan aktiva yang paling likuid atau merupakan salah satu unsur modal yang paling tinggi likuiditasnya, berarti bahwa semakin besar jumlah kas yang dimiliki oleh suatu perusahaan akan semakin tinggi pula tingkat likuiditasnya. Akan tetapi, suatu perusahaan yang mempunyai tingkat likuiditas yang tinggi karena adanya kas dalam jumlah besar berarti tingkat perputaran kas tersebut rendah dan mencerminkan adanya over investment dalam kas dan berarti pula perusahaan kurang efektif dalam mengelolah kas.

Menurut Munawir (2014:158), kas merupakan aktiva yang paling likuid atau merupakan salah satu unsur modal kerja yang paling tinggi likuiditasnya, berarti bahwa semakin besar jumlah kas yang dimiliki oleh suatu perusahaan akan semakin tinggi pula tingkat likuiditasnya. Adapun beberapa ahli mendefinisikan pengertian kas yang dikutip oleh Wardiyah (2017:213) sebagai berikut:

a. Menurut Riyanto, kas adalah salah satu unsur modal kerja yang paling tinggi tingkat likuiditasnya.

b. Menurut Harahap, kas adalah uang dan surat berharga yang dapat diuangkan setiap saat serta surat berharga lainnya yang memenuhi syarat: (1) setiap saat dapat ditukar menjadi kas, (2) tanggal jatuh temponya sangat dekat, dan (3) kecil risiko perubahan nilai yang disebabkan oleh perubahan tingkat bunga.

Dengan demikian dapat disimpulkan dari pngertian menurut ahli yang dikutip Wardiyah (2017:213) bahwa semakin besar jumlah kas yang dimiliki oleh perusahaan, akan semakin tinggi pula tingkat likuiditasnya. Hanya perusahaan yang mempunyai tingkat likuiditas yang tinggi karena adanya kas dalam jumlah yang besar berarti tingkat perputaran kas tersebut rendah dan mencerminkan over investment dalam kas dan berarti pula bahwa perusahaan kurang efektif dalam mengelolah kas. 
Sebaliknya, jika jumlah kas yang kecil, tingkat perputaran kas yang tinggi dan keuntungan yang diperoleh akan lebih besar, tetapi suatu perusahaan yang hanya mengejar keuntungan (rentabillitas) tanpa memperhatikan likuiditas akhirnya perusahaan itu dalam keadaan ilikuid apabila sewaktu-waktu ada tagihan.

2. Faktor yang Mempengaruhi Besarnya Kas

Didalam perusahaan, perubahan jumlah kas bisa saja terjadi diberbagai bidang kegiatan. Perubahan tersebut dapat menyebabkan terjadinya kekurangan kas yang mengharuskan perusahaan mencari tambahan untuk menutupi kekurangan kas diperusahaannya. Selain menyebabkan kekurangan, perubahan juga dapat menyebabkan terjadinya kelebihan kas yang mengakibatkan adanya kas menganggur (idle cash). Menurut Sujarweni (2017:177), terdapat beberapa faktor yang mempengaruhi perubahan jumlah kas, yaitu:

a. Penerimaan dari hasil penjualan barang dan jasa

Perusahaan akan mendapatkan pendapatan dari hasil kegiatan operasional perusahaan, seperti halnya penjualan. Apabila perusahaan menjual barang atau jasa secara tunai, maka perubahannya perusahaannya akan berpengaruh langsung terhadap kas perusahaan. Akan tetapi apabila perusahaan menjual secara kredit, perubahannya akan berpengaruh dimasa beberapa saat kedepan.

b. Pembelian barang dan jasa

Perusahaan membeli sejumlah barang, baik bahan baku, bahan penolong atau barang keperluan lainnya. Pembelian sejumlah barang tersebut menyebabkan berkurangnya sejumlah kas.

c. Pembayaran biaya operasional Perusahaan mengeluarkan sejumlah biaya untuk memenuhi kebutuhan aktivitas operasionalnya, seperti halnya membayar listrik, telepon, air, gaji, upah, pajak, reparasi, dan keperluan lainnya.

d. Membayar angsuran pinjaman Apabila perusahaan mengalami kekurangan dana, maka perusahaan dapat memperoleh sumber dana dengan melakukan pinjaman ke bank atau lembaga lain. Oleh karena itu, tentu saja perusahaan membayar pinjaman tersebut dengan cara mengangsur selama bebrapa waktu. Hal tersebut menyebabkan adanya pengurangan kas.

e. Pengeluaran untuk keperluan investasi

Pengeluaran untuk keperluan investasi adalah apabila perusahaan melakukan pembelian aset tetap (fixed assets) seperti halnya mesinmesin baru, pembangunan pabrik dan sebagainya.

f. Penerimaan dari pendapatan

Perusahaan memperoleh pendapatan baik secara langsung dari aktivitas operasional perusahaan maupun secara tidak langsung, yang jelas memperngaruhi jumlah kas.

g. Penerimaan dari pinjaman

Perusahaan dapat memperoleh sejumlah kas dari aktivitas operasional yang dilakukan seperti halnya penjualan dan dapat memperoleh pendapatan berupa pinjman dari lembaga 
peminjam baik bank ataupu lembaga keuagan lainnya. Pinjaman akan menambah jumlah kas dalam periode tertentu.

\section{B. Sumber dan Penggunaan Kas}

1. Sumber Penerimaan Kas

Sumber penerimaan kas disuatu perusahaan berasal dari berbagai sumber. Untuk memilih sumber penerimaan yang tepat, perusahaan dapat menentukan beberapa kriteria yang berkenaan dengan keuntungan apabila sumber penerimaan tersebut dipilih. Menurut Sujarweni (2017:179), adapun sumber kas yang dapat diluar pinjaman yaitu sebagai berikut:

a. Penjualan barang secara tunai Apabila perusahaan menjual barang atau jasa secara tunai, maka perusahaan mendapatkan kas secara langsung.

b. Pembayaran piutang

Sumber kas lainnya dapat berasal dari pembayaran piutang oleh pelanggan terutang piutang yang sudah jatuh tempo dan perusahaan dapat mengantisipasi apabila pelanggan menunda pembayaran sehingga menghambat penerimaan kas.

c. Penjualan aset tetap (fixed assets)

Apabila perusahaan dalam keadaan mendesak, perusahaan dapat menjual aktiva tetap (fixed assets) yang dimiliki. Aktiva tetap (fixed assets) yang dijual oleh perusahaan biasanya yang tidak produktif dalam kegiatan operasional perusahaan.

d. Pengeluaran saham dalam bentuk kas

Perusahaan dapat menjual saham yang dimiliki dengan pembayaran berupa uang tunai. e. Pengeluaran surat hutang jangka pendek

Perusahaan menerbitkan surat hutang jangka pendek, seperti wesel dengan jangka waktu kurang dari satu tahun.

f. Pengeluaran surat hutang jangka panjang

Perusahaan menerbitkan surat hutang jangka panjang, seperti obligasi dengan jangka waktu lebih dari satu tahun.

g. Penerimaan dari sewa

Penerimaan yang diperoleh dari hasil sewa terhadap aset yang dimiliki kepada pihaklain dalam jangka waktu tertentu.

h. Penerimaan dana sumbangan

Penerimaan dari sumbangan merupakan sumber dana yang jarang terjadi pada perusahaan komersil, tetapi masih sering terjadi pada usaha yang bersifat sosial.

i. Pengembalian kelebihan pajak

Kelebihan pembayaran pajak oleh perusahaan karena adalah kesalahan perhitungan, maka akan timbulnya pengembalian ke perusahaan.

j. Bentuk pengembalian lainnya Untuk menambah jumlah kas, maka perusahaan dapat melakukan pencarian kas dari berbagai sumber lainnya yang dapat menambah kas perusahaan.

Sedangkan menurut Jumingan (2017:97), sumber penerimaan kas suatu perusahaan pada dasarnya dapat berasal dari:

a. Hasil penjualan investasi jangka panjang, aktiva tetap baik yang berwujud maupun yang tidak berwujud (intangible aasets) atau adanya penurunan aktiva 
tidak lancar yang diimbangi dengan penambahan kas.

b. Penjualan atau adanya emisi saham maupun adanya penambahan modal oleh pemilik perusahaan dalam bentuk kas.

c. Pengeluaran surat tanda bukti utang, baik jangka pendek (wesel) maupun utang jangka panjang (utang obligasi, utang hipotik, atau utang jangka panjang yang lain) serta bertambahnya utang yang diimbangi dengan penerimaan kas.

d. Adanya penurunan atau berkurangnya aktiva lancar selain kas yang diimbangi dengan penerimaan kas pembayaran, berkurangnya persediaan barang dagangan karena adanya penjualan secara tunai, adanya penurunan surat berharga (efek) karena adanya penjualan dan sebagainya.

e. Adanya penerimaan kas karena sewa, bunga atau dividen dari investasinya,sumbangan ataupun hadiah maupun adanya pengembalian kelebihan pembayaran pajak pada periodeperiode sebelumnya.

Sedangkan menurut Wardiyah (2017:218) sumber penerimaan kas diperusahaan dapat berasal dari:

a. Hasil penjualan investasi jangka panjang, aktiva tetap (berwujud dan tidak berwujud), adanya penurunan aktiva tidak lancar yang diimbangi dengan penambahan kas.

b. Penjualan atau emisi saham ataupun penambahan modal oleh pemilik perusahaan dalam bentuk kas. c. Pengeluaran surat tanda bukti utang.

d. Penurunan atau berkurangnya aktiva lancar selain kas yang diimbangindengan adanya penerimaan kas.

e. Penerimaan kas karena sewa, bunga atau dividen dari investasinya, sumbangan atau hadiah.

Sedangkan menurut Munawir (20014:159), sumber penerimaan kas dalam suatu perusahaan pada dasarnya dapat berasal dari sebagai berikut:

a. Hasil penjualan investasi jangka panjang, aktiva tetap baik yang berwujud maupun yang tidak berwujud (intangible assets), atau adanya penurunan aktiva tidak lancar yang diimbangi dengan penambahan kas.

b. Penjualan atau adanya emisi saham maupun adanya penambahan modal oleh pemilik perusahaan dalam bentuk kas.

c. Pengeluaran surat tanda bukti hutang baik jangka pendek (wesel) maupun hutang jangka panjang (hutang obligasi, hutang hipotik atau hutang jangka panjang yang lain) serta bertambahnya hutang yang diimbangi dengan penerimaan kas.

d. Adanya penurunan atau berkurangnya aktiva lancar selain kas yang diimbangi dengan adanya penerimaan kas; misalnya adanya penurunan piutang karena adanya penerimaan pembayaran, berkurangnya persediaan barang dagangan karena adanya penjualan secara tunai, adanya penurunan surat berharga (efek) 
karena adanya penjualan dan sebagainya.

e. Adanya penerimaan kas karena sewa, bunga atau deviden dari investasinya, sumbangan atau hadiah maupun adanya pengembalian kelebihan pembayaran pajak pada periodeperiode sebelumnya.

2. Penggunaan Kas

Keseimbangan perencanaan antara penerimaan kas dan penggunaan kas sangat diperlukan pengelolaan yang baik dalam suatu perusahaan. Menurut Sujarweni (2017:180), adapun penggunaan kas antara lain sebagai berikut:

a. Pembelian barang secara tunai Perusahaan membeli sejumlah barang secara tunai untuk kegiatan operasionalnya, seperti halnya pembelian bahan baku, bahan penolong dan lainnya.

b. Pembayaran biaya

Perusahaan melakukan pembayaran, seperti halnya bayar gaji, upah, pajak maupun pengeluaran kegiatan operasional lainnya, yang dilakukan perusahaan secara mingguan bahkan bulanan.

c. Pembayaran sewa

Pembayaran yang dilakukan perusahaan berupa sewa tanah, gedung, kendaraan, mesin-mesin dan peralatan lainnya.

d. Pembayaran asuransi

Perusahaan mengeluarkan sejumlah dana untuk perlindungan usahanya dalam bentuk premi asuransi.

e. Pembayaran pajak

Perusahaan selain mengeluarkan biaya untuk keperluan operasionalnya, akan tetapi juga mengeluarkan sejumlah dana untuk pembayaran pajak yang berkaitan dengan usahanya.

f. Pembayaran iklan dan promosi lainnya

Apabila perusahaan ingin memasarkan produknya maka perusahaan mengeluarkan biaya iklan, untuk menarik minat para pembelinya.

g. Pembayaran angsuran pinjaman Perusahaan melakukan pembayaran dari pinjaman yang dilakukan dari lembaga keuangan, baik pokok maupun bunganya.

h. Pembelian surat berharga jangka pendek

Perusahaan melakukan pembelian surat berharga jangka panjang, seperti saham maupun obligasi dengan jangka waktu lebih dari satu tahun.

i. Penarikan kembali saham yang beredar

Perusahaan membeli saham yangtelah mereka jual sebelumnya dengan maksud tertentu.

j. Pengembalian kas oleh pemilik Pemilik mengambil sejumlah uangdari perusahaan dalam bentuk prive, yang digunakan untuk keperluan tertentu.

Sedangkan Menurut Munawir (2014:159), adapun penggunaan atau pengeluaran kas dapat disebabkan oleh adanya transaksi-transaksi sebagai berikut:

a. Pembelian saham atau obligasi sebagai investasi jangka pendek maupun jangka panjang serta pembelian aktiva tetap lainnya.

b. Penarikan kembali saham yang beredar maupun adanya pengembalian kas perusahaan oleh pemilik perusahaan. 
C. Pelunasan pembayaran angsuran utang jangka pendek maupun utang jangka panjang.

d. Pembelian barang dagangan secara tunai, adanya pembayaran biaya operasi yang meliputi upah dan gaji, pembelian supplies kantor, pembayaran sewa, bunga, premi asuransi, advertensi, dan adanya persekotpersekot biaya maupun persekot pembelian.

e. Pengeluaran kas untuk pembayaran dividen (bentuk pembagian laba lainnya secara tunai), pembayaran pajak, denda-denda dan sebagainya.

Sedangkan menurut Munawir (2014:159), penggunaan atau pengeluaran kas dapat disebabkan adanya transaksi-transaksi sebagai berikut:

a. Pembelian saham atau obligasi sebagai investasi jangka pendek maupun jangka panjang serta adanya pembelian aktiva tetap lainnya.

b. Penarikan kembali saham yang beredar maupun adanya pengambilan kas perusahaan oleh pemilik perusahaan.

c. Pelunasan atau pembayaran angsurann utang jangka pendek maupun utang jangka panjang.

d. Pembelian barang dagangan secara tunai, adanya pembayaran biaya operasi yang meliputi upah dan gaji, pembelian sipplies kantor, pembayaran sewa, bunga, premi asuransi, advertensi dan adanya persekotpersekot biaya maupun persekot pembelian

e. Pengeluaran kas untuk pembayaran deviden (bentuk pembagian laba lainnya secara

$$
\begin{aligned}
& \text { tunai), pembayaran } \\
& \begin{array}{l}
\text { denda-denda } \\
\text { sebagainya. }
\end{array}
\end{aligned}
$$

\section{Laporan Sumber dan Penggunaan Kas}

1. Pengertian Laporan Sumber dan Penggunaan Kas

Salah satu tujuan pokok pelaporan keuangan adalah memberikan informasi penggunaan kepada pemodal dan kreditor sekarang dan potensial serta pihak lainnya dalam membuat keputusan investasi, kredit dan sejenisnya yang rasional. Laporan dan sumber penggunaan kas memainkan peran komplementer bagi neraca dan laporan laba rugi dalam memberikan gambaran lengkap dari aset dan struktur keuangan perusahaan serta cara aset, kewajiban dan ekuitas tersebut berubah selama periode tertentu.

Adapun beberapa ahli mendefinisikan tentang pengertian laporan sumber dan penggunaan kas dalam Wardiyah (2017:227) sebagai berikut:

a. Menurut Skousen (2001:279), laporan sumber dan penggunaan kas menjelaskan perubahan selama periode didalam kas dan ekuivalen kas. Artinya, laporan sumber dan penggunaan kas ini memberikan informasi yang relevan tentang penerimaan dan pengeluaran kas suatu perusahaan pada periode tertentu dengan mengklasifikasikan transaksi pada kegiatan operasi, pembiayaan dan investasi.

b. Menurut Brigham dan Houston (2001:148), laporan sumber dan penggunaan kas adalah laporan yang menjelaskan dampak aktivitas operasi, investasi, dan pembiayaan perusahaan 
terhadap arus kas selama satu periode akuntansi. Dengan demikian, laporan keuangan yang menjelaskan informasi mengenai penerimaan dan pengeluaran kas selama periode tertentu dengan mengelompokkan transaksi pada kegiatan operasi, investasi, dan pendanaan.

Menurut Jumingan (2014:90) istilah dana (funds) disamping diartikan sebagai modal kerja (Working Capital), dalam pengertian yang lebih sempit diartikan sebagai kas (Cash). Aliran dana berupa kas dalam perusahaan dapat digambarkan sebagai proses yang bersifat terus-menerus. Secara umum aktiva yang dimiliki perusahaan merupakan bentuk penggunaan dana neto, sedang utang/pinjaman dan modal sendiri merupakan sumber dana neto. Untuk setiap penggunaan dana berarti akan mengurangi sumber dana.

Menurut Jumingan (2017:91), pada dasarnya laporan sumber-sumber dan penggunaan kas disusun melalui tahap-tahap sebagai berikut:

a. Mengelompokkan perubahan neto unsur-unsur neraca yang terjadi diantara dua titik waktu kedalam kelompok perubahan yang memperbesar jumlah kas dan kelompok perubahan yang mengurangi kas.

b. Mengelompokkan unsur-unsur laba rugi dan laporan laba yang ditahan kedalam kelompok yang memperbesar jumlah kas dan kelompok yang memperbesar jumlah kas.

c. Melakukan konsolidasi dari informasi tersebut kedalam bentuk laporan sumber-sumber dan penggunaan kas.

2. Tujuan Laporan sumber dan

\section{Penggunaan Kas}

Tujuan utama analisis sumber dan penggunaan kas adalah mengetahui sumber kas yang diperoleh selama satu periode dan untuk apa kas yang diterima tersebut. Menurut Munawir dalam Wardiyah (2017:227), tujuan penyajian laporan sumber dan penggunaan kas adalah menunjukkan perubahan kas selama satu periode dan memberikan alasan mengenai perubahan kas tersebut dengan menunjukkan asal sumber kas dan penggunaannya. Sedangkan menurut Prastowo dan Juliaty (2005:29) dalam Wardiyah (2017:228), laporan sumber dan penggunaan kas memberikan informasi untuk:

a. Mengetahui perubahan aktiva bersih, struktur keuangan, dan kemampuan memengaruhi arus kas.

b. Menilai kemampuan perusahaan dalam menghasilkan kas dan setara kas.

c. Mengembangkan model untuk menilai dan membandingkan nilai sekarang arus kas masa depan dari berbagai perusahaan.

d. Menggunakan informasi arus kas historis sebagai indikator jumlah waktu dan kepastian arus kas masa depan.

e. Meneliti kecermatan taksiran arus kas masa depan dan menentukan hubungan antara profitabilitas dan arus kas bersih serta dampak perubahan harga.

f. Mengetahui kemampuan perusahaan dalam menghasilkan laba, mengendalikan penerimaan, dan pengeluaran kas serta informasi mengenai return dari sumber kekayaan perusahaan.

3. Manfaat Laporan sumber dan Penggunaan Kas 
Untuk mengetahui dan memahami kondisi perusahaan dalam waktu tertentu, manajemen perusahaan dapat membuat laporan sumber dan penggunaan kas. Membuat laporan sumber dan penggunaan kas sangat diperlukan bagi perusahaan agar aktivitas yang berhubungan dengan kas dapat dapat diketahui oleh manajemen. Menurut Sujarweni (2017:182), manfaat laporan sumber dan penggunaan kas antara lain:

a. Untuk mengetahui ada tidaknya perubahan penggunaan kas.

b. Untuk mengetahui ada tidaknya perubahan terhadap sumbersumber kas.

c. Untuk mengetahui apakah sumber dan penggunaan kas telah dilakukan secara efektif dan efisien.

d. Untuk mengetahui sebab-sebab perubahan kas, baik berupa sumber maupun penggunaan kas.

e. Sebagai salah satu dasar pertimbangan bagi kreditor untuk menilai kemampuan perusahaan dalam membayar bunga dan pinjamannya.

f. Sebagai alat untuk perencanaan kas mendatang.

g. Untuk mengetahui kebutuhan perusahaan dimasa mendatang.

\section{Laporan Aliran Kas}

Menurut Munawir (2008:113) laporan aliran atau arus kas disusun untuk menunjukkan perubahan kas selama satu periode dan memberikan penjelasan mengenai alas an perubahan tersebut dengan menunjukkan dari mana sumber penerimaan kas dan untuk apa penggunaannya. Laporan arus kas terbagi atas 3 aktivitas, Munawir (2008:117):
1. Aktivitas Operasi

Jumlah arus kas yang berasal dari aktivitas operasi didifinisikan sebagai seluruh transaksi penerimaan kas yang berkaitan dengan pendapatan penjualan dan kas keluar yang berkaitan dengan biaya operasi, termasuk pembayaran kepada pemasok barang atau jasa, pembayaran upah dan pajak. Beberapa contoh arus kas yang diperoleh dari aktivitas operasi adalah sebagai berikut:

a. Penerimaan kas dari penjualan barang dan jasa.

b. Penerimaan kas dari royalty, komisi dan pendapatan lainnya.

c. Pembayaran kas kepada pemasok barang atau jasa.

d. Penerimaan dan pembayaran kas kontrak yang diadakan untuk tujuan transaksi usaha perdagangan.

e. Pemberian kredit oleh lembaga keuangan.

2. Aktivitas Investasi

Aktivitas investasi meliputi perolehan aktiva jangka panjang termasuk pembelian surat berharga yang tidak setara dengan kas dan peminjaman uang (loan receivable) serta kebalikannya yaitu penjualan ativa jangka panjang dan pelunasan pinjaman. Namun kenaikan atau penurunan piutang usaha dan persediaan tidak diperlakukan sebagai aktivitas investasi karena perubahan tersebut terjadi pada aktiva lancar maka harus diklasifikasikan sebagai aktivitas operasi. Beberapa contoh arus kas yang berasal dari aktivitas operasi adalah sebagai berikut:

a. Pembayaran kas untuk membeli aktiva tetap, aktiva tak berwujud, biaya pengembangan yang direkapitalisasi dan aktiva tetap yang dibangun sendiri. 
b. Penerimaan kas dari penjualan tanah, bangunan dan peralatan, aktiva tak berwujud dan aktiva jangka panjang lainnya.

c. Perolehan saham atau instrument keuangan perusahaan lain.

d. Uang muka penjualan yang diberikan kepada pihak lain serta pelunasannya (kecuali yang dilakukan oleh lembaga keuangan).

3. Aktivitas Pendanaan

Meliputi aktivitas peminjaman uang yang meliputi utang obligasi dan bentuk utang jangka panjang lainnya dan emisi saham baru, pembayaran kembali pinjaman jangka panjang. Pembayaran deviden kepada pemegang saham, dan penggunaan untuk penarikan kembali saham perusahaan. Namun demikian, perubahan pada utang usaha, utang upah dan gaji, utang bunga dan utang pajak tidak diperlakukan sebagai aktivitas pendanaan, melainkan sebagai aktivitas operasi. Beberapa contoh arus kas yang berasal dari aktivitas pendanaan adalah sebagai berikut:

a. Penerimaan kas dari emisi saham atau instrument modal lainnya.

b. Pembayaran kas kepada para pemegang saham untuk menarik atau menebus sahm perusahaan.

c. Penerimaan kas dari emisi obligasi, pinjaman, wesel dan pinjaman lainnya.

d. Pelunasan pinjaman.

\section{E. Penyusunan Laporan Sumber dan Penggunaan Kas}

1. Penyusunan Laporan Perubahan Sumber dan Penggunaan Kas

Penyusunan laporan perubahan

kas atau laporan sumber dan penggunaan kas dapat dilakukan dengan meringkas jurnal penerimaan kas dan jurnal pengeluaran kas. Cara ini memakan waktu yang lama karna harus menggolong-golognkan setiap transaksi kas menurut sumbernya masing-masing serta tujuan penggunaannya, dan cara ini hanya dapat dilakukan oleh internal analis yang memungkinkan memperoleh datanya dengan lengkap dan masih murni. Bagi eksternal analis maka penyusunan laporan sumber dan penggunaan kas dapat dilakukan dengan menaganalisa perubahan yang terjadi dalam laporan keuangan yang diperbandingkan antara dua waktu atau akhir periode serta informasi-informasi lain yang mendukung terjadinya perubahan tersebut.

Menurut Jumingan (2014:99), penyusunan laporan perubahan kas atau laporan sumber dan penggunaan kas dapat dilakukan dengan meringkas jurnal penerimaan kas dan jurnal pengeluaran kas. Cara ini memakan waktu yang lama karena harus menggolongkan setiap transakasi kas menurut sumbernya masing-masing serta tujuannya dan cara ini dapat dilakukan oleh internal analisis yang memungkinkan memperoleh datanya dengan lengkap dan masih murni. Bagi eksternal analisis, menyusun laporan sumber dan penggunaan kas dapat dilakukan dengan menganalisis perubahan yang terjadi dalam laporan keuangan yang diperbandingkan antara dua waktu atau akhir periode serta informasi-informasi lain yang mendukung terjadinya perubahan tersebut. Dalam menganalisis perubahan yang terjadi harus diperhatikan kemungkinan adanya perubahan atau transaksi yang tidak mempengaruhi kas (Noncash Transaction).

Menurut Jumingan (2017:99), 
transaksi-transaksi yang tidak mempengaruhi uang kas antara lain sebagai berikut:

a. Adanya pengakuan atau pembebanan depresiasi, amortisasi dan deplesi terhadap aktiva tetap, Intangible Assets, dan Wasting Assets. Biaya depresiasi ini merupakan biaya yang tidak memerlukan pengeluaran kas.

b. Pengakuan adanya kerugian piutang baik dengan membentuk cadangan kerugian piutang maupun tidak, dan penghapusan piutang karena piutang yang bersangkutan sudah tidak dapat ditagih lagi.

c. Adanya penghapusan atau pengurangan nilai buku dari aktiva yang dimiliki dan penghentian dari penggunaan dari aktiva tetap karena aktiva yang bersangkutan telah habis disusut dan atau sudah tidak dapat dipakai lagi.

d. Adanya pembayaran Stock Devidend (Dividen dalam bentuk saham), adanya penyisihan atau pembatasan penggunaan laba, dan adanya penilaian kembali (revaluasi) terhadap aktiva tetap yang dimiliki perusahaan.

2. Penggunaan Kertas Kerja

Apabila jumlah pos-pos atau rekening yang nampak dalam neraca yang diperbandingkan relative sedikit dan jumlah transaksi atau perubahan yang terjadi masih sederhana atau tidak begitu rumit (complicated) maka penyusunan laporan perubahan kas dapat disusun secara langsung menganalisa perubahan yang bersangkutan. Tetapi kalau jumlah pos atau rekening neraca relatif banyak, dan jumlah informasi-informasi lain juga cukup banyak serta perubahan atau transaksi-transaksi yang mengakibatkan perubahan tersebut begitu rumit maka penyusunan laporan perubahan kas akan menemui kesulitan bila dilakukan secara langsung, oleh karena itu untuk membantu memecahkan persoalan tersebut maka sebelum menyusun laporan perubahan kas sebaiknya disusun kertas kerja atau work sheet sebagaimana dibuat dalam penyusunan laporan perubahan modal kerja.

Menurut Munawir (2014:169), bentuk work sheet untuk perubahan kas terdiri dari delapan kolom yang prosedur penyusunannya adalah sebagai berikut:

a. Mendaftar pos-pos neraca yang diperbandingkan antara dua titik waktu tertentu dalam kolom pertama dan kedua, pisahkan antara kelompok debit dan kredit.

b. Mendaftar pos-pos laporan laba rugi dari tahun yang diperbandingkan (current year), susunlah dalam kredit dan debit pada kolom pertama dan kedua.

c. Tentukan kenaikan dan penurunan yang terjadi padapospos neraca, tunjukkan dalam kolom "Perubahan" debit dan kredit. Kolom perubahan debit untuk mencatat adanya kenaikan aktiva, penurunan hutang dan modal serta bertambahnya biaya serta berkurangnya penghasilan sedangkan kolom kredit untuk mencatat penurunan aktiva, kenaikan hutang dan modal serta pertambahan penghasilan dan berkurangnya biaya.

d. Menganalisa perubahanperubahan yang terjadi pada pos-pos neraca dan pos-pos laba 
rugi untuk menentukan adanya perubahan yang tidak mempengaruhi kas.

e. Membuat jurnal penyesuaian dalam work sheet tersebut untuk menghilangkan akibat atau pengaruh non kas yang sudah dicatat dalam periode tersebut.

f. Memindahkan saldo setelah disesuaikan (kecuali perubahan kas) kedalam kolom "Kenaikan dan Penurunan Kas" atau "Sumber dan Penggunaan Kas". Penurunan aktiva (selain kas), kenaiakan hutang, modal dan penghasilan merupakan sumber kas sedangkan kenaikan aktiva (selain kas), penurunan hutang, modal dan kenaikan biaya merupakan penggunaan kas. Perubahan dalam kas tidak perlu dipindahkan ke kolom sumber dan penggunaan kas karena perubahan kas inilah yang dianalisa selisih jumlah kolom sumber kas dengan penggunaan kas harus sama dengan perubahan yang terjadi dalam pos "Kas"

\section{III.METODE PENELITIAN}

Penelitian ini dilakukan pada perusahaan PT. Bank Rakyat Indonesia (Persero), Tbk Periode 2018-2019 yang diperoleh datanya melalui alamat website Indonesia Stock Exchange (IDX) www.idx.co.id. Jenis data yang digunakan adalah data kualitatif dan dan Kuantitatif, adapun sumber data yang digunakan adalah data sekunder. Metode pengumpulan data yang digunakan oleh penulis ini adalah penelitian kepustakaan (library research).

\section{Metode Analisis}

Metode yang digunakan adalah metode deskriptif analisis yaitu metode dengan cara mengumpulkan data dan mendiskriptifkan atau menjelaskan data-data tersebut. Jumingan (2017:91) laporan sumber-sumber dan penggunaan kas merupakan metode atau cara untuk mengetahui perubahan neto dari aliran dana kas antara dua titik waktu, dua titik waktu tersebut berupa tanggal penyusunan laporan keuangan pada awal dan akhir suatu periode yang akan dianalisis. Pada dasarnya laporan sumber-sumber dan penggunaan kas disusun melalui tahap-tahap sebagai berikut:

1. Mengelompokkan perubahan neto unsur-unsur neraca yang terjadi diantara dua titik waktu kedalam kelompok perubahan yang memperbesar kas dan kelompok perubahan yang mengurangi kas.

2. Mengelompokkan unsur-unsur laba rugi dan laporan laba yang ditahan dalam kelompok yang memperbesar jumlah kas dan kelompok yang mengurangi jumlah kas.

3. Melakukan konsolidasi dan informasi-informasi tersebut kedalam bentuk laporan sumber dan penggunaan kas.

Menurut Jumingan (2017:91) adapun susunan laporan sumber dan penggunaan kas yang dibuat secara singkat sebagai berikut:

a. Sumber kas di peroleh dari:

1) Berkurangnya/penurunan neto aktiva lancar selain kas.

2) Berkurangnya atau penurunan aktiva tidak lancar.

3) Bertambahnya (kenaikan neto) setiap jenis utang.

4) Hasil penjualan atau pengeluaran saham prioritas atau saham biasa.

5) Keuntungan dari operasi 
perusahaan.

b. Penggunaan kas diperoleh dari:

1) Bertambahnya (kenaikan neto) aktiva lancar selain kas.

2) Bertambahnya (kenaikan bruto) aktiva tidak lancar

3) Berkurangnya (penurunan neto)

Tabel 1: Ringkasan Unsur-Unsur Sumber dan Penggunaan Kas

\begin{tabular}{|l|l|l|}
\hline Keterangan & Sumber Kas & Penggunaan Kas \\
\hline Aktiva lancar selain kas & $(-)$ & $(+)$ \\
\hline Aktiva tetap & $(-)$ & $(+)$ \\
\hline Utang lancar & $(+)$ & $(-)$ \\
\hline Utang jangka panjang & $(+)$ & $(-)$ \\
\hline Modal & $(+)$ & $(-)$ \\
\hline Laba perusahaan & $(+)$ & $(-)$ \\
\hline
\end{tabular}

Sumber: Jumingan, 2017.

\section{HASIL PENELITIAN DAN PEMBAHASAN}

\section{A. Analisis Sumber Dan Penggunaan Kas}

Berdasarkan laporan neraca dan laba rugi periode tahun 2018-sampai setiap jenis utang.

4) Penarikan atau pembelian modal saham.

5) Pembayaran dividen tunai.

6) Adanya kerugian dalam operasi perusahaan.

Tabel 2: Laporan Sumber dan Penggunaan kas PT. Mulia Industrindo, Tbk. 31 Desember 2018 sampai 31 Desember 2019 (dalam ribuan Rupiah)

\begin{tabular}{|l|c|l|c|}
\hline \multicolumn{2}{|c|}{ Sumber-sumber kas berasal dari: } & \multicolumn{2}{c|}{ Penggunaan kas berasal dari } \\
\hline Laba bersih tahun berjalan & 126.773 .341 & $\begin{array}{l}\text { Bertambahnya aset keuangan } \\
\text { lainnya }\end{array}$ & 140.611 .874 \\
\hline $\begin{array}{l}\text { Berkurangnya piutang usaha } \\
\text { pihak berelasi }\end{array}$ & 12.998 .003 & $\begin{array}{l}\text { Bertambahnya piutang usaha } \\
\text { pihak ketiga }\end{array}$ & 40.609 .143 \\
\hline Berkurangnya uang muka & 14.325 .273 & $\begin{array}{l}\text { Bertambahnya piutang lain- } \\
\text { lain pihak berelasi }\end{array}$ & 175.214 \\
\hline $\begin{array}{l}\text { Berkurangnya biaya dibayar } \\
\text { dimuka }\end{array}$ & 1.016 .017 & $\begin{array}{l}\text { Bertambahnya piutang lain- } \\
\text { lain pihak ketiga }\end{array}$ & 1.455 .430 \\
\hline $\begin{array}{l}\text { Berkurangnya aset pajak } \\
\text { tangguhan }\end{array}$ & 58.232 .567 & Bertambahnya persediaan & 28.335 .104 \\
\hline $\begin{array}{l}\text { Bertambahnya utang bank } \\
\text { Bang }\end{array}$ & 3.467 .731 & $\begin{array}{l}\text { Bertambahnya uang muka } \\
\text { pembelian aset tetap }\end{array}$ & 108.641 .859 \\
\hline $\begin{array}{l}\text { Bertambahnya utang usaha } \\
\text { pihak ketiga }\end{array}$ & 4.578 .994 & $\begin{array}{l}\text { Bertambahnya pajak dibayar } \\
\text { bertambahnya aset tetap }\end{array}$ & 107.112 .977 \\
\hline $\begin{array}{l}\text { Bertambahnya utang lain-lain } \\
\text { pihak ketiga }\end{array}$ & 3.146 .306 & $\begin{array}{l}\text { Berkurangnya utang usaha- } \\
\text { pihak berelasi }\end{array}$ & 62.034 .739 \\
\hline $\begin{array}{l}\text { Bertambahnya utang lain-lain } \\
\text { pihak berelasi }\end{array}$ & & 20.311 .177 \\
\hline
\end{tabular}

dengan 2019, mengenai rincian sumber dan penggunaan kas pada PT. Mulia Industrindo, Tbk., dibuat laporan sumber dan penggunaan kas sebagai berikut: 


\begin{tabular}{|c|c|c|c|}
\hline $\begin{array}{l}\text { Bertambahnya biaya yang } \\
\text { masih harus dibayar }\end{array}$ & 12.778 .160 & $\begin{array}{l}\text { Berkurangnya utang lain-lain } \\
\text { pihak ketiga }\end{array}$ & 403.784 \\
\hline $\begin{array}{l}\text { Bertambahnya uang muka } \\
\text { penjualan }\end{array}$ & 35.299 .750 & Berkurangnya utang pajak & 58.072 .257 \\
\hline $\begin{array}{l}\text { Bertambahnya liabilitas jangka } \\
\text { panjang yang jatuh tempo- } \\
\text { utang bank }\end{array}$ & 87.353 .271 & $\begin{array}{l}\text { Berkurangnya utang liabilitas } \\
\text { jangka panjang yang jatuh } \\
\text { tempo-utang lain-lain pihak } \\
\text { ketiga }\end{array}$ & 120.397 .819 \\
\hline Bertambahnya utang lain-lain & 175.459 .256 & $\begin{array}{l}\text { Berkurangnya Liabilitas } \\
\text { pajak tangguhan }\end{array}$ & 19.510 .120 \\
\hline $\begin{array}{l}\text { Bertambahnya liabilitas jangka } \\
\text { panjang-utang bank }\end{array}$ & 45.311 .058 & & \\
\hline $\begin{array}{l}\text { Bertambahnya liabilitas } \\
\text { imbalan kerja }\end{array}$ & 47.843 .991 & & \\
\hline Bertambahnya modal disetor & 93.622 .064 & & \\
\hline $\begin{array}{l}\text { Bertambahnya penghasilan } \\
\text { komprehensif lain }\end{array}$ & 23.359 .515 & & \\
\hline $\begin{array}{l}\text { Bertambahnya biaya perolehan } \\
\text { saham yang diperoleh }\end{array}$ & 23.359 .515 & & \\
\hline \multirow[t]{3}{*}{ Jumlah sumber kas } & 788.957 .896 & Jumlah penggunaan kas & 707.671 .597 \\
\hline & & Peningkatan kas & 81.386.299 \\
\hline & & Total & 788.957.896 \\
\hline
\end{tabular}

Sumber: Data diolah, 2020.

Berdasarkan Laporan Sumber dan Penggunaan Kas pada PT. Mulia Industrindo, Tbk dapat dilihat bahwa terjadi peningkatan kas sebesar Rp. 81.286.299, hal ini terjadi karena sumber kas yang dimiliki sebesar Rp. 788.957.896 lebih besar dibandingkan penggunaan kas sebesar Rp. 707.671.597.

Dari seluruh sumber kas yang ada, yang memberikan kontribusi yang besar berasal dari sumber yang paling menonjol adalah liabilitas jangka panjang utang bank sebesar Rp. 175.459.256. Adanya laba operasi bersih sebesar Rp. 126.773.341, artinya ada peningkatan laba yang merupakan sumber kas.

$$
\text { Bertambahnya utang bank }
$$

sebesar Rp. 95.801.909, berarti ada tambahan kas yang berasal dari utang bank yang merupakan sumber kas. Bertambahnya utang usaha pihak ketiga sebesar Rp. 3.467.731 , berarti ada tambahan kas dari utang usaha pihak ke tiga. Bertambahnya utang lain-lain pihak berelasi sebesar Rp. 4.578.994, berarti adanya penambahan kas dari utang lain-lain pihak berelasi.

Bertambahnya biaya yang masih harus dibayar sebesar Rp. 3.146.306, berarti ada tambahan kas dari biaya yang masih harus dibayar yang merupakan sumber kas. Berkurangnya biaya dibayar dimuka sebesar $\mathrm{Rp}$. 1.016.017, yang merupakan sumber kas.

Berkurangnya piutang usaha pihak berelasi sebesar Rp. 12.998.003. Bertambahnya penghasilan 
komprehensif lain sebesar Rp. 93.622.064, yang merupakan sumber kas. Bertambahnya biaya porelehan saham yang diperoleh kembali sebesar Rp. 23.359.515 yang merupakan sumber kas. Bertambahnya tambahan modal disetor sebesar Rp. 47.843.991. Bertambahnya liabilitas imbalan kerja sebesar Rp.45.311.058. Berkurangnya uang muka sebesar Rp. 14.235.273. Bertambahnya liabilitas jangka panjang lain-lain sebesar Rp. 87.353.271. Bertambahnya liabilitas jangka panjang yang jatuh tempo dalam waktu satu tahun sebesar Rp. 35.299.750. berkurangnya aset pajak tangguhan sebesar Rp. 5.823.257. Bertambahnya uang muka penjualan sebesar Rp. 17.778.160.

Sedangkan penggunaan kas yang paling menonjol adalah untuk aset keuangan lainnya sebesar Rp. 140.611.874, berarti terdapat kas yang digunakan untuk membayar aset keuangan lainnya.

Pembayaran liabilitas jangka panjang yang jatuh tempo dalam waktu satu tahun sebesar Rp. 120.397.819, berarti terdapat kas yang digunakan untuk membayar liabilitas jangka panjang yang merupakan sumber kas. Penambahan uang muka pembelian Aset tetap sebesar Rp. 108.641.859, berarti perusahaan sedang melakukan expansi lebih lanjut yang merupakan penggunaan kas. Bertambahnya persediaan sebesar Rp. 28.355.104 berarti ada kas yang digunakan untuk persediaan yang merupakan penggunaan kas.

Berkurangnya utang usaha pihak ketiga sebesar Rp. 40.609.143, berarti ada pembayaran utang usaha pihak ketiga yang merupakan penggunaan kas. Penambahan aset tetap sebesar Rp. 107.112.977 berarti perusahaan sedang melakukan expansi lebih lanjut yang merupakan penggunaan kas. Bertambahnya pajak dibayar dimuka sebesar Rp. 20.311.177, berarti ada pembayaran pajak dibayar di muka yang merupakan penggunaan kas. Bertambahnya piutang lain-lain pihak ke tiga sebesar Rp. 1.455.430, artinya ada pembayaran piutang lain-lain pihak ke tiga yang merupakan penggunaan kas. bertambahnya piutang lain-lain pihak berelasi sebesar Rp. 175.214.

Berkurangnya utang lain-lain pihak ketiga sebesar Rp. 403.784, berarti ada pembayaran utang lain-lain yang merupakan penggunaan kas. berkurangnya utang pajak sebesar Rp. 58.072.357, berarti ada pembayaran utang pajak yang merupakan penggunaan kas. berkurangnya liabilitas pajak tangguhan sebesar Rp. 19.510.120.

Untuk laporan sumber dan penggunaan kas ada peningkatan kas, dimana hal tersebut disebabkan adanya sumber kas yang lebih besar dibandingkan penggunaan kas.

\section{B. Tabel Work Sheet}

Berdasarkan hasil analisis perubahan neraca dari laporan sumber dan penggunaan kas, berikut ini tabel work sheet sumber dan penggunaan kas pada PT. Mulia Industrindo, Tbk adalah sebagai berikut: 
Tabel : Work sheet sumber dan penggunaan kas pada PT. Mulia Industrindo, Tbk., periode 31 Des 2018 sampai 31 Des 2019 (dalam ribuan rupiah)

\begin{tabular}{|c|c|c|c|c|c|c|}
\hline \multirow{2}{*}{ pos-pos neraca } & \multicolumn{2}{|c|}{31 Des } & \multicolumn{2}{|c|}{ Perubahan } & \multicolumn{2}{|c|}{ kas } \\
\hline & 2018 & 2019 & D & $\mathbf{K}$ & sumber & penggunaan \\
\hline \multicolumn{7}{|l|}{ ASET } \\
\hline \multicolumn{7}{|l|}{ Aset Lancar } \\
\hline Kas dan bank & 55.917 .194 & 137.203 .493 & 81.286 .299 & & & 81.286 .299 \\
\hline $\begin{array}{ll}\begin{array}{l}\text { Aset } \\
\text { lainnya }\end{array} & \text { keuangan } \\
\end{array}$ & 111.658 & 140.723 .532 & 140.611 .874 & & & 140.611 .874 \\
\hline $\begin{array}{l}\text { Piutang usaha - } \\
\text { Pihak berelasi }\end{array}$ & 24.143 .331 & 11.145 .328 & & 12.998 .003 & 12.998 .003 & \\
\hline $\begin{array}{l}\text { Piutang usaha - } \\
\text { Pihak ketiga }\end{array}$ & 444.065 .886 & 484.675 .029 & 40.609 .143 & & & 40.609 .143 \\
\hline $\begin{array}{l}\text { Piutang lain-lain - } \\
\text { Pihak berelasi }\end{array}$ & 259.329 & 434.543 & 175.214 & & & 175.214 \\
\hline $\begin{array}{l}\text { Piutang lain-lain } \\
\text { pihak ketiga }\end{array}$ & 3.215 .976 & 4.671 .406 & 1.455 .430 & & & 1.455 .430 \\
\hline Persediaan & 576.382 .814 & 604.717 .918 & 28.335 .104 & & & 28.335 .104 \\
\hline $\begin{array}{ll}\text { Pajak } & \text { dibayar } \\
\text { dimuka } & \\
\end{array}$ & 15.092 .678 & 35.403 .855 & 20.311 .177 & & & 20.311 .177 \\
\hline Uang muka & 29.277 .320 & 14.952 .047 & & 14.325 .273 & 14.325 .273 & \\
\hline $\begin{array}{ll}\begin{array}{l}\text { Biaya } \\
\text { dimuka }\end{array} & \text { dibayar } \\
\end{array}$ & 3.459 .185 & 2.443 .168 & & 1.016 .017 & 1.016 .017 & \\
\hline $\begin{array}{l}\text { Jumlah } \\
\text { Lancar }\end{array}$ & 1.151.925.371 & 1.436 .370 .319 & & & & \\
\hline \multicolumn{7}{|l|}{ Aset Tidak Lancar } \\
\hline $\begin{array}{l}\text { Uang muka } \\
\text { pembelian aset tetap }\end{array}$ & 8.893 .332 & 117.535 .191 & 108.641 .859 & & & 108.641 .859 \\
\hline $\begin{array}{ll}\begin{array}{l}\text { Aset } \\
\text { tangguhan }\end{array} & \text { pajak } \\
\end{array}$ & 24.005 .383 & 18.182 .126 & & 5.823 .257 & 5.823 .257 & \\
\hline Investasi saham & 400.000 & 400.000 & & & & \\
\hline Aset tetap & 4.076.950.726 & 4.184 .063 .703 & 107.112 .977 & & & 107.112 .977 \\
\hline Aset lain-lain & 1.551 .287 & 1.551 .287 & & & & \\
\hline $\begin{array}{l}\text { Jumlah Aset Tidak } \\
\text { Lancar }\end{array}$ & 4.111.800.728 & 4.321.732.307 & & & & \\
\hline Jumlah ASET & 5.263.726.099 & 5.758.102.626 & & & & \\
\hline $\begin{array}{l}\text { LIABILITAS DAN } \\
\text { EKUITAS }\end{array}$ & & & & & & \\
\hline \multicolumn{7}{|l|}{ LIABILITAS } \\
\hline \multicolumn{7}{|l|}{$\begin{array}{l}\begin{array}{l}\text { Liabilitas } \\
\text { Pendek }\end{array} \\
\end{array}$} \\
\hline Utang bank & 107.754 .700 & 203.556.609 & & 95.801 .909 & 95.801 .909 & \\
\hline $\begin{array}{l}\text { Utang usaha - pihak } \\
\text { berelasi }\end{array}$ & 62.034 .739 & - & 62.034 .739 & & & 62.034 .739 \\
\hline $\begin{array}{l}\text { Utang usaha - pihak } \\
\text { ketiga }\end{array}$ & 356.285 .792 & 359.753 .523 & & 3.467 .731 & 3.467 .731 & \\
\hline $\begin{array}{l}\text { Utang lain-lain - } \\
\text { pihak berelasi }\end{array}$ & 35.442 .604 & 40.021 .598 & & 4.578 .994 & 4.578 .994 & \\
\hline $\begin{array}{l}\text { Utang lain-lain } \\
\text { pihak ketiga }\end{array}$ & 32.131 .532 & 31.727 .748 & 403.784 & & & 403.784 \\
\hline $\begin{array}{l}\text { Biaya yang masih } \\
\text { harus dibayar }\end{array}$ & 175.497 .941 & 178.644 .247 & & 3.146 .306 & 3.146 .306 & \\
\hline Utang pajak & & & & & & \\
\hline
\end{tabular}




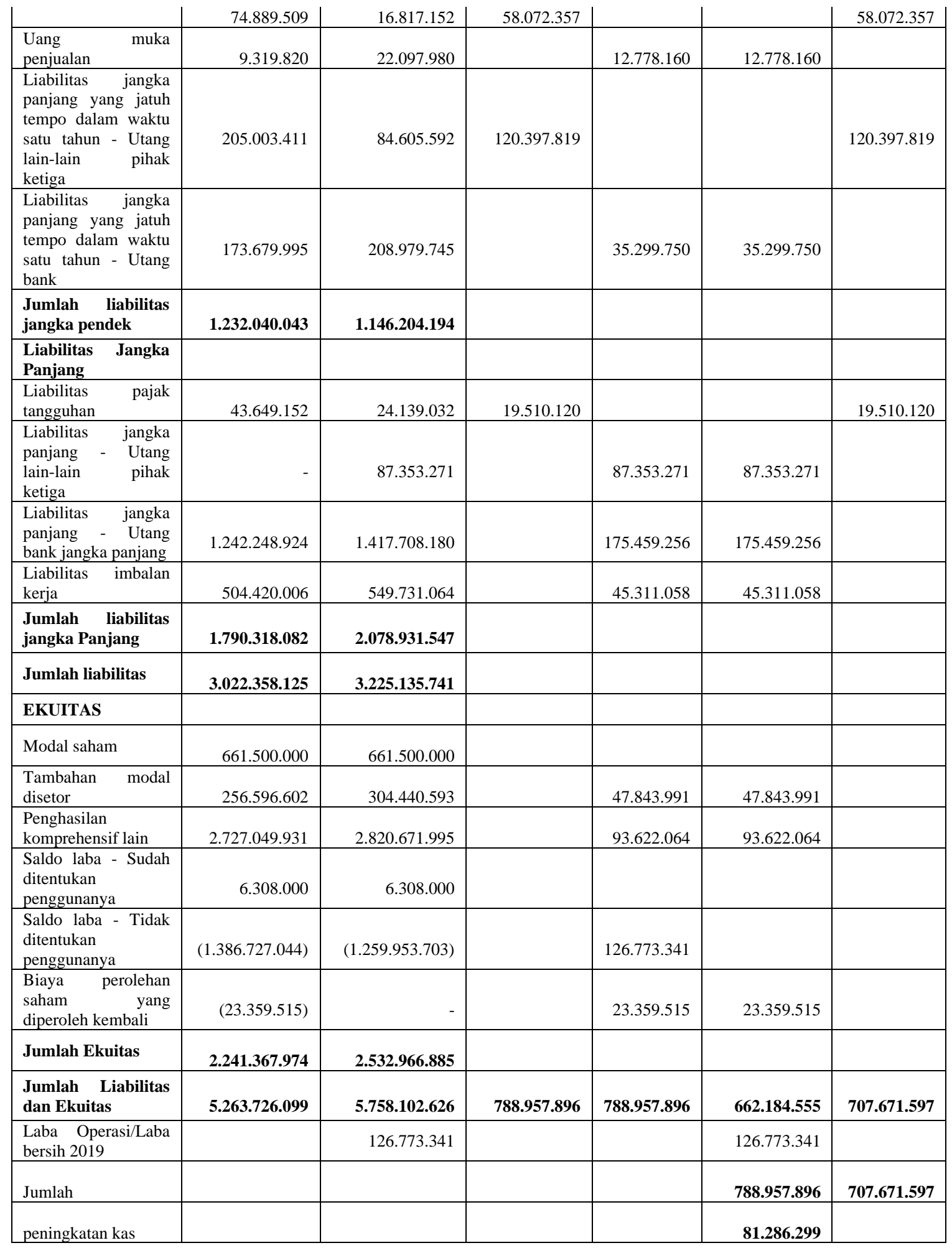

Sumber: Data diolah, 2020.

Berdasarkan tabel Work Sheet diatas terlihat bahwa Work Sheet diatas terbagiatas Asset lancar, Asset tidak lancar, Liabilitas jangka pendek, Liabilitas jangka panjang, 
dan Ekuitas. Seperti diketahui pada tabel sebelumnya yaitu pada laporan keuangan PT. Mulia Industrindo, Tbk. dimana data tersebut dimasukkan kedalam Work Sheet guna mempermudah atau mempersiapkan penyusunan laporan sumber dan penggunaan kas

Dari tabel Work Sheet tersebut, maka dapat disimpulkan bahwa tahun 2019 perusahaan memperoleh asset sebesar $\mathrm{Rp}$. 5.758.102.626 yang mengalami peiningkatan dibandingkan pada tahun 2018 dengan jumlah asset sebesar Rp 5.263.726.099 dimana penurunan asset sebesar Rp 494.376.527.

Selanjutnya untuk tabel sumber dan penggunaan kas, diketahui bahwa sumber kas pada PT. Mulia Industrindo, Tbk. tahun 2018 - 2019 sebesar Rp 788.957.895 dan penggunaan kas sebesar Rp 707.671.597, adapun kenaikan kas sebesar Rp. 81.286.299. Hal ini terutama disebabkan oleh kenaikan pada penerimaan kas dari pelanggan, penerimaan penghasilan bunga serta penurunan pada pembayaran kas pada pemasok dan berkurangnya pembayaran beban keuangan.

\section{KESIMPULAN DAN SARAN a. Kesimpulan}

Berdasarkan hasil penelitian dan analisa yang telah dilakukan dapat ditarik kesimpulan bahwa analisis sumber dan penggunaan kas pada PT. Mulia Industrindo, Tbk. Dari tahun 2018 sampai 2019 terjadi peningkatan kas sebesar Rp. 81.286.299 Hal ini terjadi karena kas dan setara kas pada tahun 2018 sebesar Rp 55.917.194 dan meningkat pada tahun 2019 sebesar Rp 137.203.493 Sumber kas pada tahun 2019 sebesar Rp 788.957.896 sedangkan penggunaan kas tahun 2019 sebesar Rp 707.671.597 sumber kas terbesar di tahun 2019 berasal dari Liabilitas jangka panjang utang bank sebesar Rp. 175.459.256, sedangkan penggunaan kas terbesar di tahun 2019 berasal dari Aset keuangan lainnya sebesar Rp. 140.611.874 sehingga dapat disimpulkan bahwa sumber kas lebih besar dari penggunaan kas.

\section{b. Saran}

Saran yang dapat diajukan oleh penulis sehubungan dengan kesimpulan sebagai masukan bagi PT. Mulia Industrindo, Tbk. adalah mengamati perkembangan sumber dan penggunaan kas pada PT. Mulia Industrindo, Tbk. menunjukkan tingkat perubahan meningkat, maka diketahui bahwa pihak PT. mulia Industrindo, Tbk. telah memiliki sumber dan penggunaan kas yang baik. Sebagai salah satu perusahaan terkemuka, sangat diharapkan agar kualitas pelayanan dan hasil produksi yang baik dan dipertahankan.

\section{DAFTAR PUSTAKA}

1) Fahmi, Irham. 2017. Analisis Laporan Keuangan. Cetakan Ke 6. Alfabeta, Bandung.

2) Hery. 2016. Financial Ratio For Business; Analisis Keuangan Untuk Menilai Kondisi Financial dan Kinerja Perusahaan. PT Grasindo, Jakarta.

3) Jumingan. 2017. Analisis Laporan Keuangan. Cetakan 
Ke 6. PT Bumi Aksara. Jakarta.

4) Kasmir. 2017. Analisis Laporan Keuangan. Cetakan $\mathrm{Ke}$ 10. PT Rajagrafindo Persada. Jakarta.

5) Mulyawan, Setia. 2015. Manajemen Keuangan. Cetakan 1. CV Pustaka Setia, Bandung.

6) Munawir, S. 2014. Analisis Laporan Keuangan. Edisi Ke 4. Penerbit Liberty. Yogyakarta.

7) Riyanto, Bambang. 2013. Dasar-Dasar Pembelanjaan Pembelanjaan Perusahaan. Edisi ke 4. Penerbit PBFE. Yogyakarta.

8) Sujarweni, V. Wiratna. 2017. Manajemen Keuangan; Teori, Aplikasi dan Hasil Penelitian. Pustaka Baru Pres, Yogyakarta.

9) Sustrisno. 2017. Manajemen Keuangan; Teori Konsep dan Aplikasi. Cetakan 1. Penerbit EKONISIA, Yogyakarta.

10) Wardiyah, Mia Lasmi. 2017. Analisis Laporan Keuangan cetakan. 1. CV Pustaka Setia, bandung. 